\title{
The Importance of Research on Alternative and Hybrid Rock Extraction Methods
}

\author{
Nikolaus August Sifferlinger, Philipp Hartlieb, and Peter Moser \\ Chair of Mining Engineering and Mineral Economics, Montanuniversitaet Leoben, Leoben, Austria
}

Received December 26, 2016; accepted December 29, 2016; published online January 27, 2017

\begin{abstract}
Current methods of mechanical excavation of rock are limited in regard to the material which can be extracted economically. The use of roadheaders with pick tools has the advantage of high flexibility in form of turn off radii down to $1 \mathrm{~m}$ but is limited by rock strength to figures below $150 \mathrm{MPa}$ UCS.

While mechanical rock excavation machines with disc cutters can handle rock strengths above $150 \mathrm{MPa}$, they are limited to turn off radii $>12 \mathrm{~m}$. This issue is discussed in detail and shown in this paper.

Therefore there is presently a significant "Gap" for a method (other than drill \& blast) of rock extraction for turn off radii below $12 \mathrm{~m}$ and rock strengths above $150 \mathrm{MPa}$ UCS.

This gives the motivation of R\&D into alternative extraction methods which could lead to new combined methods covering this "Gap".
\end{abstract}

Keywords: Mechanical rock extraction, Continuous mining, Hard rock, Alternative extraction methods, Roadheader

Die Notwendigkeit, auch im Bereich der alternativen und hybriden Gesteinslöseverfahren zu forschen

Zusammenfassung: Für die derzeit verfügbaren Methoden des mechanischen Lösens von Gestein gibt es in Bezug auf den ökonomischen Einsatz erhebliche Einschränkungen. Teilschnittmaschinen mit einem Schneidkopf mit Meißelbestückung sind sehr flexibel in Bezug auf den Abzweigradius, allerdings ist nach derzeitiger Entwicklung bei einer Gesteinsfestigkeit von rund $150 \mathrm{MPa}$ UCS die Grenze des wirtschaftlich sinnvollen Einsatzes erreicht.

Univ.-Prof. DI. Dr. mont. N. A. Sifferlinger ( $\square)$ Chair of Mining Engineering and Mineral Economics, Montanuniversitaet Leoben,

Franz-Josef-Str. 18,

8700 Leoben, Austria

nikolaus-august.sifferlinger@unileoben.ac.at
Maschinen mit Schneiddisken können zwar viel höhere Gesteinsfestigkeiten lösen, die Flexibilität in Bezug auf den Abzweigradius ist jedoch auch bei den neuesten Entwicklungen auf $>12 \mathrm{~m}$ beschränkt. Der Stand der Technik wird ausführlich dargestellt und diskutiert.

Daher besteht derzeit eine "Lücke" für eine Methode des kontinuierlichen Gesteinslösens (zusätzlich zum Sprengbetrieb) für Abzweigradien kleiner $12 \mathrm{~m}$ und in Gesteinsfestigkeiten über $150 \mathrm{MPa}$ UCS.

Schlüsselwörter: Mechanisches Gesteinslösen, Kontinuierlicher Vortrieb, Hartgestein, Alternative Lösemethoden, Teilschnittmaschine

\section{Introduction/Problem Statement}

Current methods of mechanical excavation are limited by the rock strength and abrasivity on the one hand and by the machine size and capability of the tools on the other side.

Although blasting operation is the most economic for mass mining in the cyclic entry development in increasing depths in underground mines, it has severe disadvantages. Some of these are safety during blasting, need for time to ventilate the blast fumes, safety of storage, transport and handling of explosives, possible damage to entry profile; over-break and profile.

Beside research into improved drill \& blast equipment and operation (e.g. mechanization and automation of the process [1]) there is a trend to search for continuous rock extraction methods like mechanical cutting.

There is a need for

- Fast excavation of hard rock (UCS range from 150 to $300 \mathrm{MPa}$ )

- Flexible excavation

- Low energy consumption

- Little environmental impact

- Increased safety 
Figure 1: Mechanical cuttingneed to close the present Gap in the area of high rock strength and high flexibility in regard to small radius (Moser/Hartlieb/ Sifferlinger)

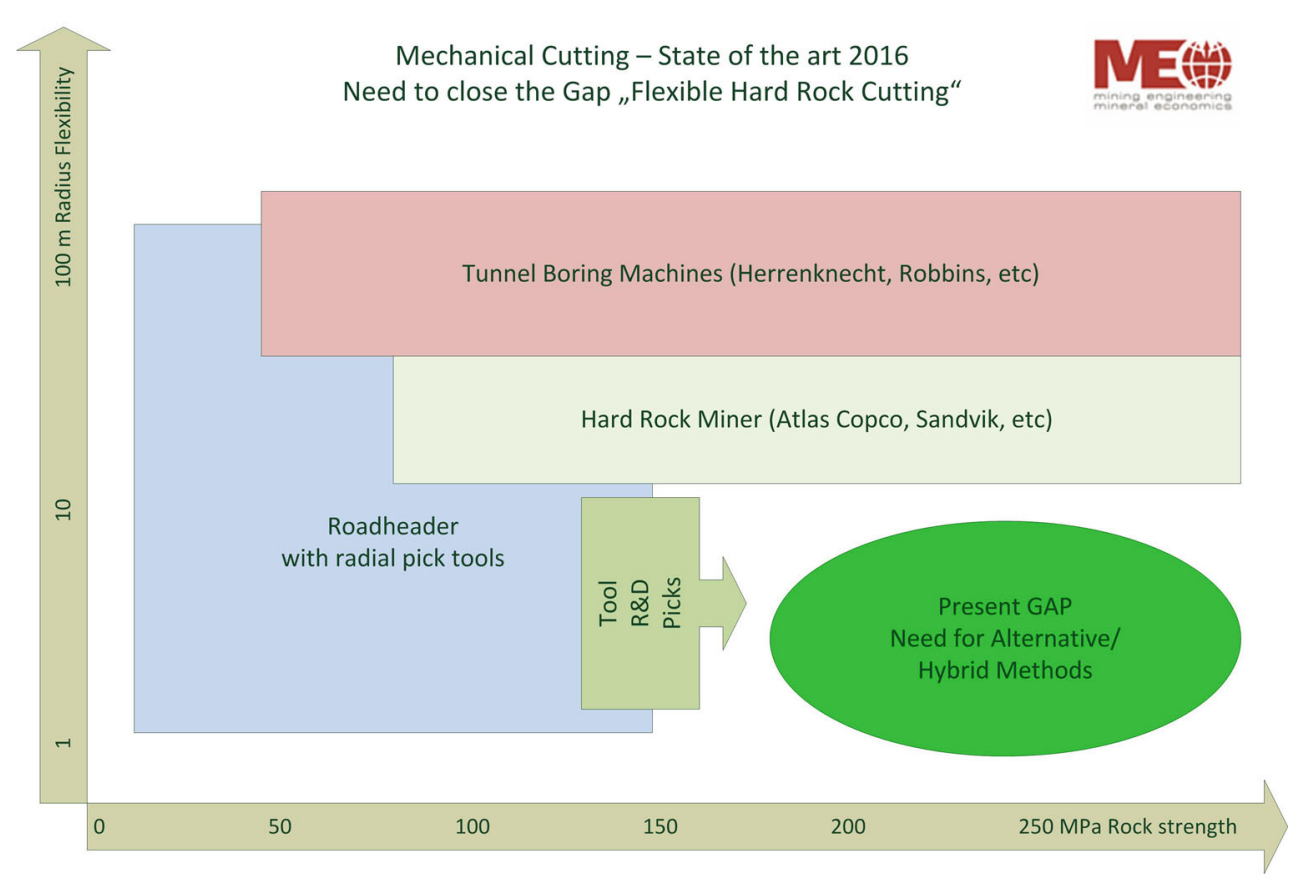

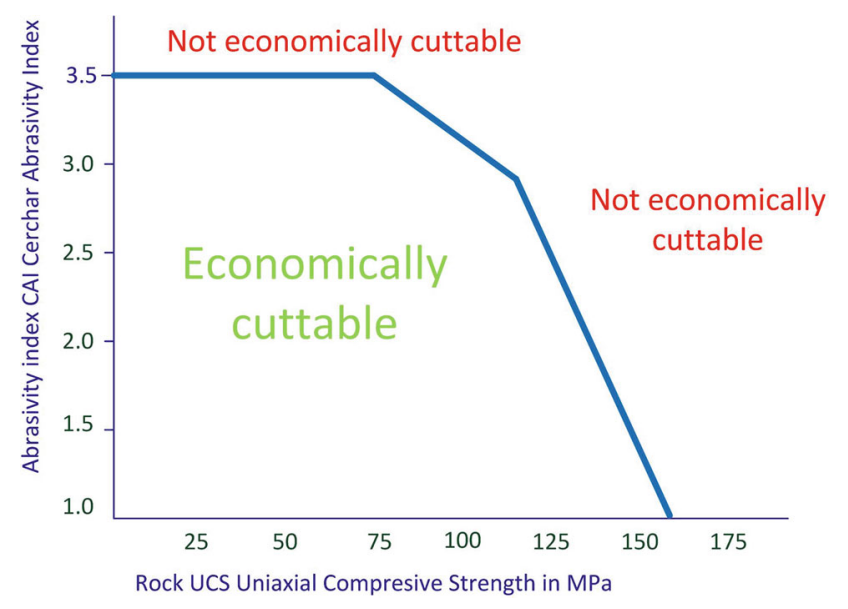

Figure 2: Range of UCS and CAI of natural rocks and the areas of economic cuttability with pick tools of a roadheader as with tools available in the year 2016

\section{- Economic rock extraction.}

When it comes to flexible advance also regarding the radius of the entry development for mechanical cutting, only the roadheader concept is flexible enough to cut turnoffs etc.

But the cutting tools of the roadheader have their limits concerning rock strength and abrasivity.

Despite in-depth research by several companies, like Element 6, Kennametal or Sandvik, in the last two decades the limit of usage has only been shifted higher very slightly. Presently it cannot be predicted if and when new materials like diamond composites will lead to a break-through with this type of tools.

Figure 1 gives a rough, simplified overview of the situation in 2016, comparing mechanical cutting systems in regard to the rock strength and the flexibility in proportion to turn off radii. It must be kept in mind that not all that is presently being developed by the OEMs of mining equipment is public and one can only hope for good results in $R \& D$.

As there is a significant "Gap" for rock extraction in rock strength UCS higher than $150 \mathrm{MPa}$ and flexibility in turn off radius $<12 \mathrm{~m}$, this is an important area for $R \& D$ at Montanuniversitaet Leoben and its partners.

The various existing methods shown in Fig. 1 are discussed in the following parts.

\section{Roadheader}

A roadheader is an excavation machine, mounted on tracks for mobility, with a boom mounted cutter head, a loading device which feeds into a conveyor. Today the cutter head for rock applications is fitted with pick tools. The lifetime of the present pick tools in higher rock strength and abrasivity is the major limiting factor for roadheader use in hard rock [2] - see Fig. 2.

But also the geometric configuration and the machine weight are of important influence [3] as shown in Fig. 3.

It is also essential to know that the cutting performance in $\mathrm{m}^{3} / \mathrm{h}$ is sinking with increasing UCS and abrasivity.

A roadheader can cut a $90^{\circ}$ turnoff in entry development as long as the entry width is broad enough to allow the roadheader to manoeuvre (typically 6 to $8 \mathrm{~m}$ ). For this reason the roadheader can swivel its cutter boom and rear conveyor in order to get around the corner.

\section{Tool Development for Roadheaders}

Cemented tungsten carbide pick tools have reached a certain limit regarding the rock properties they can cut eco- 


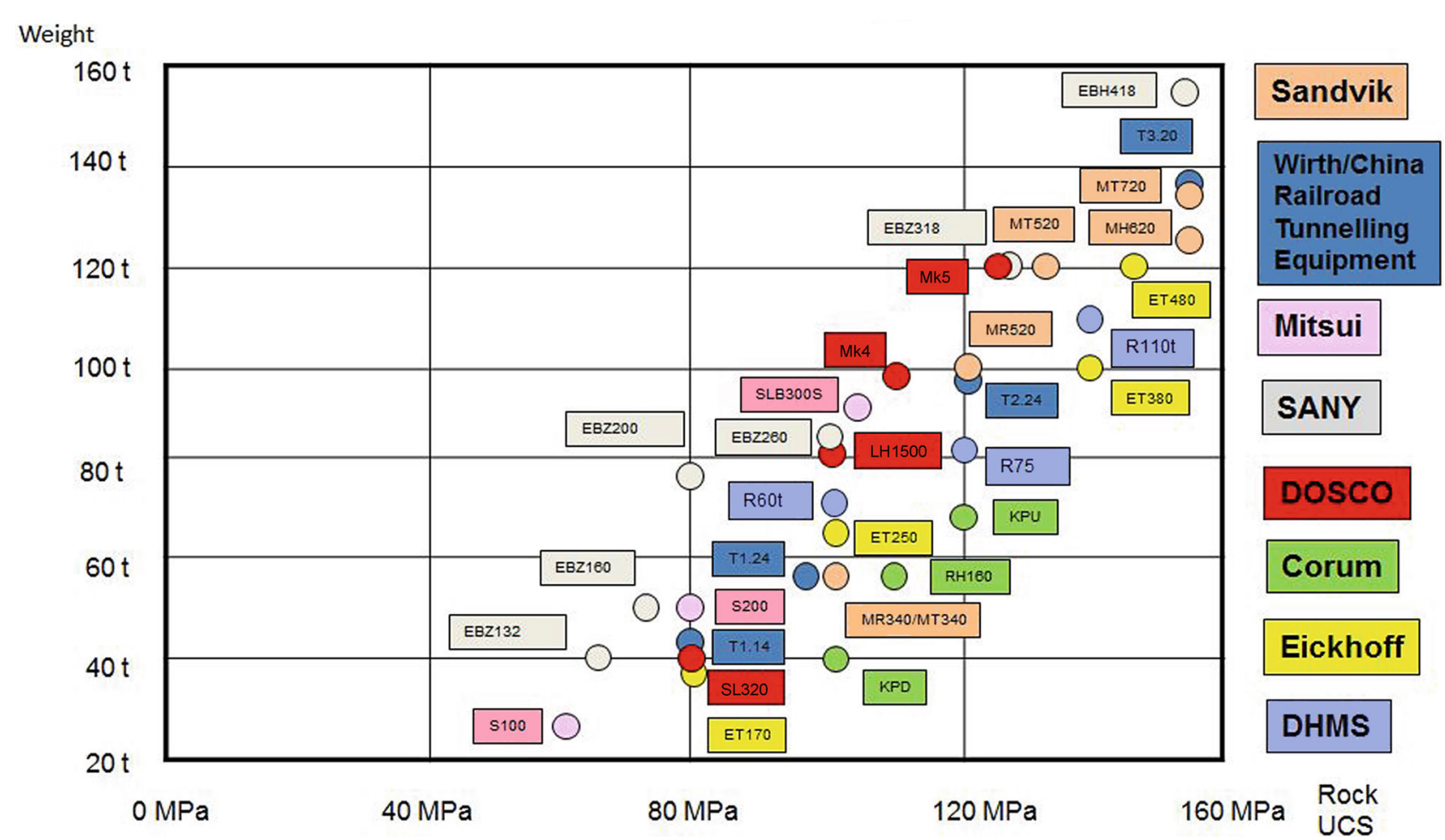

Figure 3: Relation of roadheader weight against maximum operation area in regard to rock UCS as stated by the manufacturers in 2015 (Sifferlinger)

Figure 4: Hardness and abrasivity classification of rock for tool by Sandvik [4] (Source: Sandvik) [4]

\begin{tabular}{|l|l|l|l|}
\hline \multicolumn{2}{|l|}{ Hardness Classification of Rock } & \multicolumn{2}{l|}{ Abrasivity Classification of Rock } \\
\hline Description & Compressive strength (MPa) & Description & CERCHAR Abrasivity Index (CAI) \\
\hline Soft & $\sigma<30$ & Low & CAl $<1.0$ \\
\hline Medium & $20<\sigma<50$ & Moderate & $1.0<$ CAl $<2.0$ \\
\hline Hard & $40<\sigma<80$ & High & $2.0<$ CAl $<3.0$ \\
\hline Extreme & $80<\sigma$ & Extreme & $3.0<$ CAl \\
\hline
\end{tabular}

nomically as shown in Fig. 2. In the last 15 years $R \& D$ in this type of tools has only yielded improvements in the range of a few percents.

Figure 4 shows the present classification for cemented carbide tools by Sandvik, who is one of the leading companies for this type of tools.

Therefore research into cutting tools using synthetic diamond based materials has been intensified in the last decade. Element 6 is leading the research in this area and offers long lasting tools with polycrystalline diamond tips (PCD) for use in coal mining (cf. Fig. 5).

During cutting tests PCD tools have performed well under stable cutting conditions for UCS up to $220 \mathrm{MPa}$, but as soon as there occurred irregularities in the guidance of the PCD tool they tended to disintegrate abruptly. It seems that they are not stable against pull or impact forces.

As on the other side PCD tools produce less dust and do not generate sparks in the UCS range $<120 \mathrm{MPa}$, they fit perfectly for coal mining with touching the side stones sometimes for short periods.
But for hard rock with UCS >160 MPa the PCD pick tools need more R\&D and it cannot be predicted if a breakthrough can be achieved in the near future.

Consequently, the performance of roadheaders in hard rock is limited by the available tools.

\section{Tunnel Boring Machines (TBM)}

Tunnel boring machines with a circular full-cut cutter head equipped with disc cutters can cut rock up to $300 \mathrm{MPa}$ [6].

In order to achieve the necessary advance in the rock, disc cutters of tunnel boring machines need a force of up to 32 t per cutting tool $[7,8]$.

Therefore tunnel boring machines need to be able to apply high thrusting forces which they do with grippers against the rock walls. Levant Ozdemir et al. [9] looked into the application of tunnel boring machines in underground mine development. Looking at Figure 6, which gives the data of the TBMs used at San Manuel Mine of Magma Cop- 


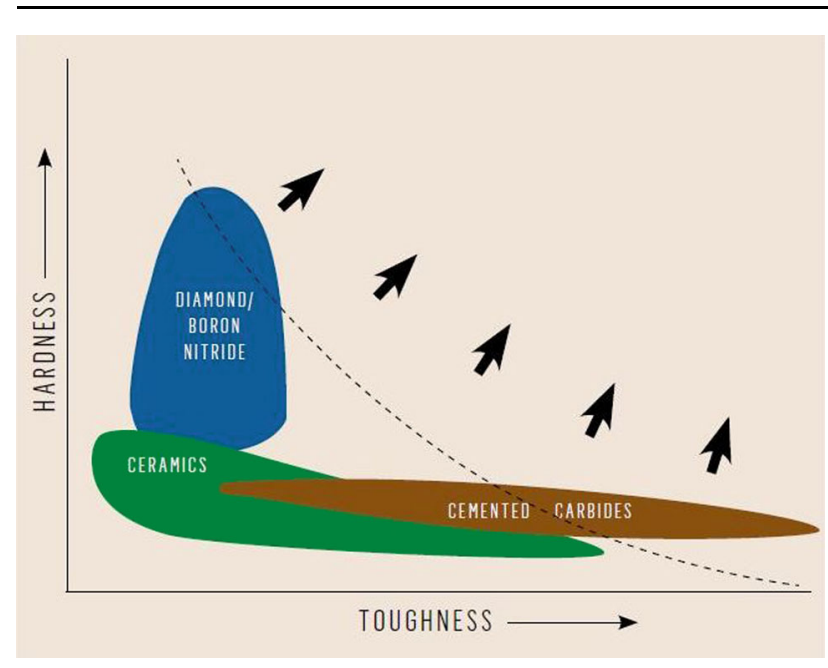

Figure 5: Application area of cutting pick tools for rock in mining and tunnelling according to Element 6 [5] (Source: Element 6) [5]

\begin{tabular}{|l|l|l|}
\hline Mine & San Manuel Mine & Stillwater Mine \\
\hline Manufacturer & Robbins TBM & CTS TBM \\
\hline Boring diameter & $4.62 \mathrm{~m}$ & $4.58 \mathrm{~m}$ \\
\hline Cutterhead installed power & $1259 \mathrm{~kW}$ & $1345 \mathrm{~kW}$ \\
\hline Cutterhead RPM & $4-12$ & $11.6 / 3.8$ \\
\hline Cutterhead thrust & $7340 \mathrm{kN}$ & $8545 \mathrm{kN}$ \\
\hline Cutter discs number & 33 & 29 \\
\hline Cutter disc tip width & $15.875 \mathrm{~mm}$ & $15.875 \mathrm{~mm}$ \\
\hline Cutter disc diameter & $432 \mathrm{~mm}$ & $26 \times 432 \mathrm{~mm}$ \\
& & $3 \times 406 \mathrm{~mm}$ \\
\hline Boring stroke & $1,575 \mathrm{~m}$ & $1,220 \mathrm{~m}$ \\
\hline Minimum turning radius & $105 \mathrm{~m}$ & $61 \mathrm{~m}$ \\
\hline Weight & $225 \mathrm{t}$ & $275 \mathrm{t}$ \\
\hline
\end{tabular}

Figure 6: TBM Examples in mining use (Source: L. Ozdemir et al)

per Company in Arizona and at Stillwater Mine in Montana show that flexibility is not the strong side of these machines.

\section{New Types of Hardrock Mining Machines}

\subsection{Aker Wirth}

Aker Wirth developed the Mobile Tunnel Miner with disc undercutting technology and first did a short test operation in Canadian copper/nickel mining in 1993. Revived with new technology, a new Mobile Tunnel Miner was constructed for Rio Tinto and commenced underground trials at Northparkes copper/gold mine in Australia in April 2013. The tests were stopped when the mine was sold and no test results have been available so far [10], (Fig. 7, 8).

The Mobile Tunnel Miner is designed for rock UCS from 50 to $260 \mathrm{MPa}$ and the MTM 4 model has a $12 \mathrm{~m}$ turning radius. The planned advance rate in development is up to $12 \mathrm{~m}$ per day.
In February 2013 it was announced that a Mobile Tunnel Miner was intended for a test operation in 2014 at Chuquicamata mine in Chile [11]. This test operation was never accomplished due to the changes at Aker Wirth.

\subsection{Atlas Copco}

Atlas Copco developed the Mobile Miner, based on the concept of the Robbins Mobile Miner, tested at Broken Hill Mine in the 1990s. The new prototype was constructed for Rio Tinto in USA, but the test operation was cancelled because of the global crisis in commodity prices. Now it is scheduled to go to Anglo America as Rapid Mine Development System in the Twickenham Platinum Mine in South Africa [12]. The tests commenced at the end of 2016, yielding promising results (Fig. 9, 10).

So the Atlas Copco Mobile Miner as built today has a turning radius of $65 \mathrm{~m}$, and practical operation will show the upper economical limit in regard to cuttable rock strength. A big advantage is that the results of the Robins Mobile Miner operation in Broken Hill in the 1990s were taken into consideration.

\subsection{Caterpillar}

Caterpillar developed the Caterpillar Rock Straight System, which is a longwall mining system for reef mining [13], (Fig. 11). It is also understood that a similar cutting system for use on a roadheader is under development, but no official data available so far.

The Rock Straight System is designed for reef mining in abrasive material and is therefore not suitable for the development of roadways. From the cutter head design it will be interesting to see the size of the cut material and the tear and wear for rock with UCS >150 MPa.

\subsection{Joy Mining}

Joy Mining and CRC Mining have been working together since 2006 with the oscillating disc cutter called DynaCut ${ }^{\mathrm{TM}}$ and have also done tests with $80 \mathrm{MPa}$ waterjets to support the cutting process [14], (Fig. 12). The Joy Global DynaCut machine is scheduled to go for a test site in 2016 [15].

The roadheader concept gives this system a high flexibility. But the application of a single oscillating cutting disc raises questions regarding the amount of extracted material per hour. In road development the question how to achieve the undercut free space to start is not solved. It will be interesting to see the results of the planned tests in this regard.

\subsection{Sandvik}

The Cutting Technology for rock at the location Zeltweg in Austria looks back on a long history. In the late 1950s 
Figure 7: Aker Wirth MTM4

(Source: Aker Wirth)

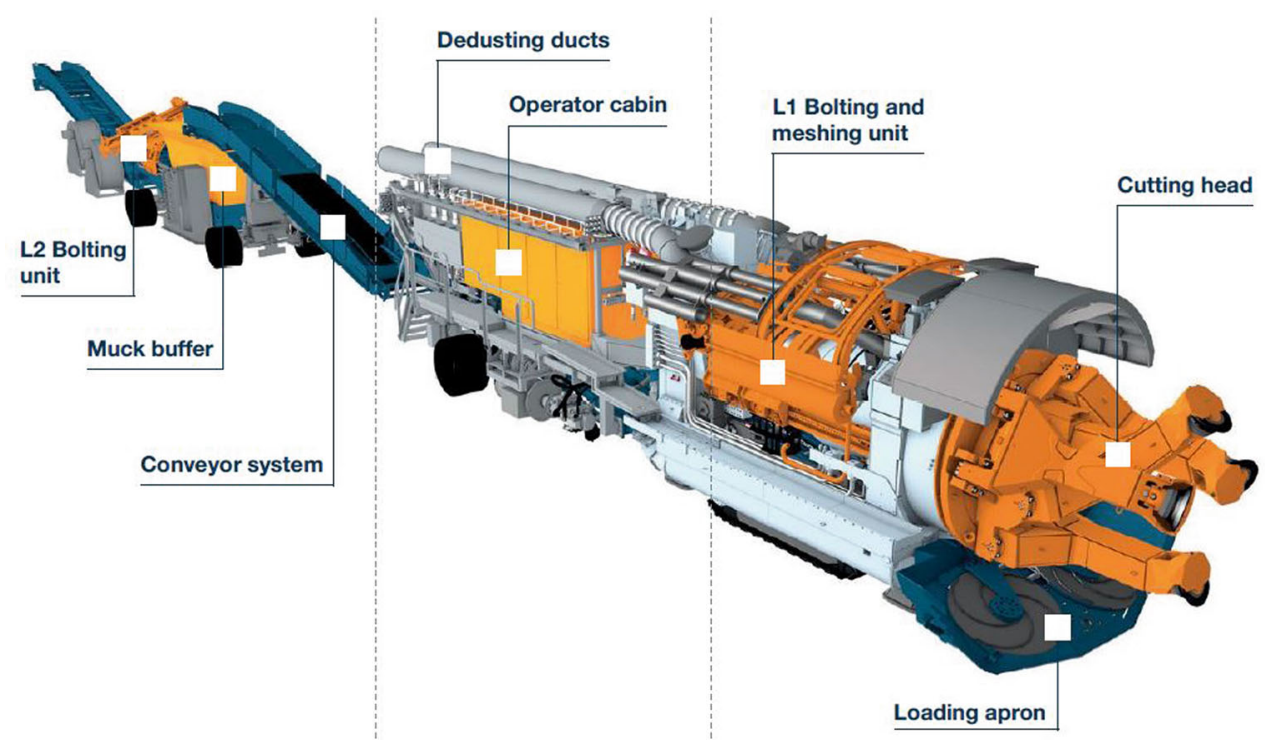

\section{Carrier}

\begin{tabular}{|l|l|l|}
\hline & MTM4 & MTM6 \\
\hline Maximum tunnel diameter & $6.2 \mathrm{~m}$ & $6.2 \mathrm{~m}$ \\
\hline Overall weight & $230 \mathrm{t}$ & $407 \mathrm{t}$ \\
\hline Overall length incl. back up & $48 \mathrm{~m}$ & $75 \mathrm{~m}$ \\
\hline Cutter head speed & $0-24 \mathrm{rpm}$ & $0-24 \mathrm{rpm}$ \\
\hline Maximum cutting head torque & $550 \mathrm{kNm}$ & $740 \mathrm{kNm}$ \\
\hline Disc cutter size & $560 \mathrm{~mm}$ & $560 \mathrm{~mm}$ \\
\hline Disc cutter thrust & $250 \mathrm{kN}$ & $250 \mathrm{kN}$ \\
\hline Number of arms & 4 & 6 \\
\hline Turning radius & $12 \mathrm{~m}$ & $30 \mathrm{~m}$ \\
\hline Operating gradient (inclined/declined tunnel) & $+9^{\circ} /-2^{\circ}$ & $+/-2^{\circ}$ \\
\hline
\end{tabular}

Figure 8: Aker Wirth MTM4 and MTM6 main data (Source: Aker Wirth)

Figure 9: The Atlas Copco Mobile Miner as built for Rio Tinto (Source: Atlas Copco)

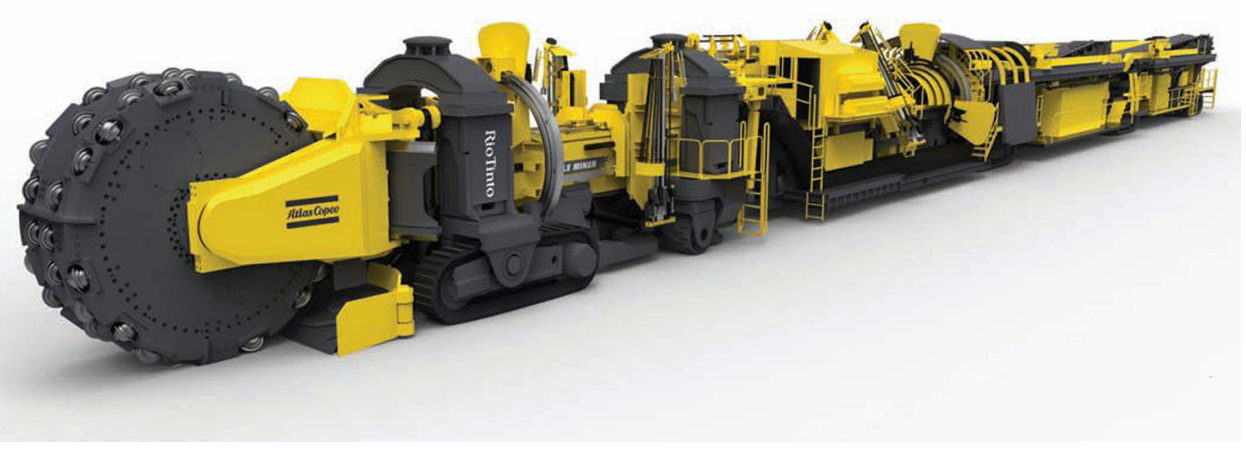




\begin{tabular}{|l|l|}
\hline Width cross section & $4.2 \mathrm{~m}$ \\
\hline Standard height & $5.5 \mathrm{~m}$ \\
\hline Cross section & $24 \mathrm{~m}^{2}$ \\
\hline Incline cutting & $18 \%$ \\
\hline Decline cutting & $15 \%$ \\
\hline Minimum horizontal turning radius & $65 \mathrm{~m}$ at $6.5 \mathrm{~m}$ tunnel width \\
\hline Minimum vertical curve radius & $200 \mathrm{~m}$ \\
\hline Gripper pad ground pressure & $8 \mathrm{MPa}$ top \& bottom \\
\hline Best cutting performance in & 50 to $150 \mathrm{MPa}$ \\
\hline Total weight & $700 \mathrm{t}$ \\
\hline
\end{tabular}

Figure 10: Technical Data of Atlas Copco Mobile Miner in 2015 (Source: Atlas (opco)

Figure 11: Caterpillar Rock Straight System (Source: Caterpillar)

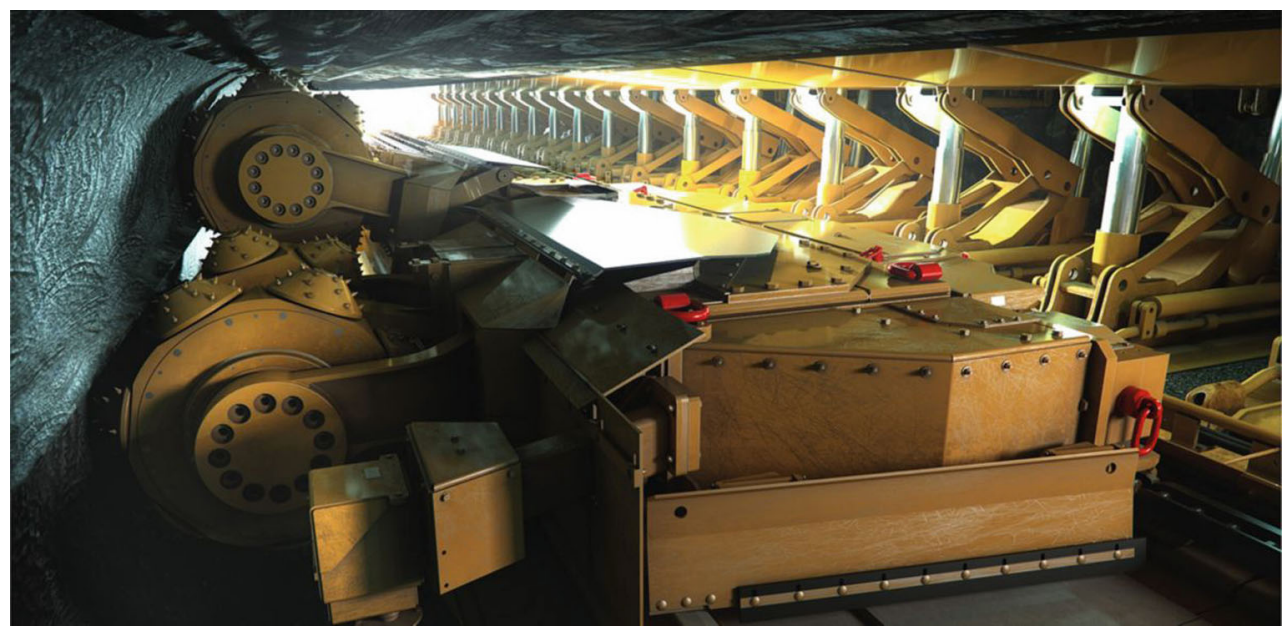

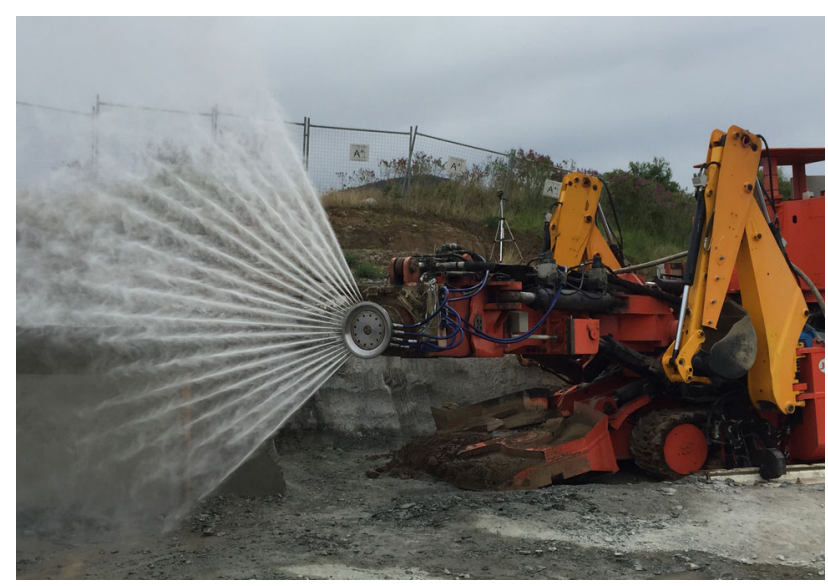

Figure 12: Joy Global DynaCut machine with $80 \mathrm{MPa}$ water jet assisted oscillating cutter disc (Source: CRC Mining)

the Wohlmeyer undercutting machine was developed and brought into operation there [16], (Fig. 13, 14).

Around 2004, Sandvik Mining and Construction developed the Reef Miner ARM 1100, which was operationally tested in the abrasive platinum reef in South Africa and in copper mining in Poland. In the beginning, the lifetime of the cutter discs was a limiting factor. ARM1100 is designed for following the reef, so the flexibility is low and the cutting discs are built to withstand a high abrasivity and rock strength $>200 \mathrm{MPa}$.

For Rapid Mine Development the Sandvik MX650 with roller disc undercutting technology is built and scheduled to be tested at the tungsten mine in Mittersill in 2017. The machine seems to be stabilized by grippers to handle the cutting reaction forces. The minimum turn off radius for this system is expected to be $12 \mathrm{~m}$ and rock strength up to $250 \mathrm{MPa}$ is in the focus (Fig. 15).

\section{Alternative Methods of Rock Extraction}

So closing this present "Gap" above 150 MPa rock strength and entry development radii $<12 \mathrm{~m}$ is not possible with a "simple" improvement of the tools in operation.

There is research necessary in alternative and hybrid methods which will be able to (pre-) damage the rock in a way that makes classical mechanical excavation more feasible in the problem fields described above.

Beside R\&D aiming at "mechanizing and automation" of drill\&blast to make it more flexible and "micro blasting" 


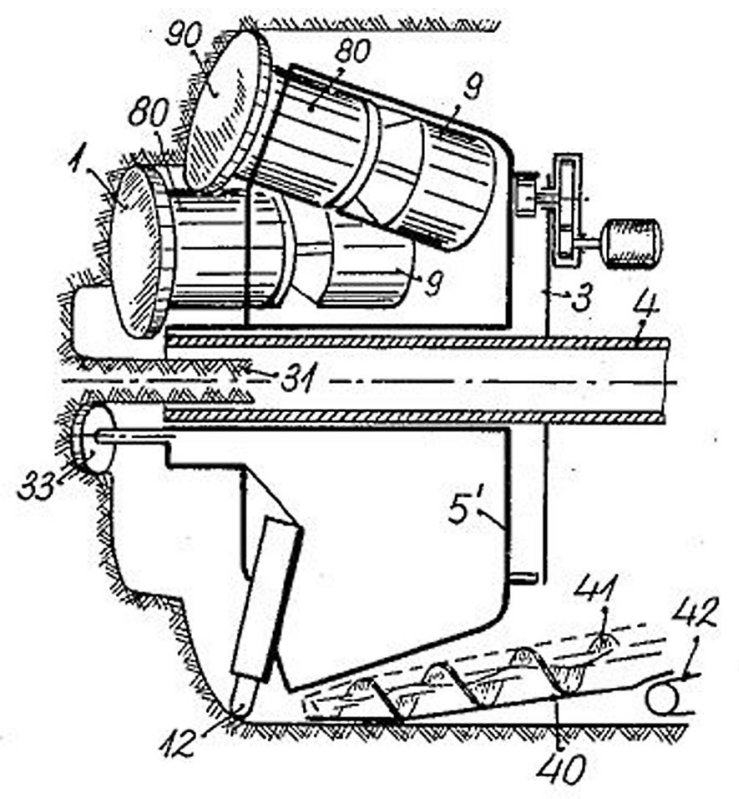

\section{INVENTOR. Vosef Wohlmeyer}

Figure 13: Excerpt from US Patent US 2,758,825 from 14 August 1956 showing the undercutting principle by Dipl.-Ing. JosefWohlmeyer. The machine was built by Alpine Montan in Zeltweg

Figure 14: Alpine Wohlmeyer undercutting machine for road development at Karlschacht

Coal Mine in Koeflach/Austria in 1958 (Source: MUL/Fettweis)

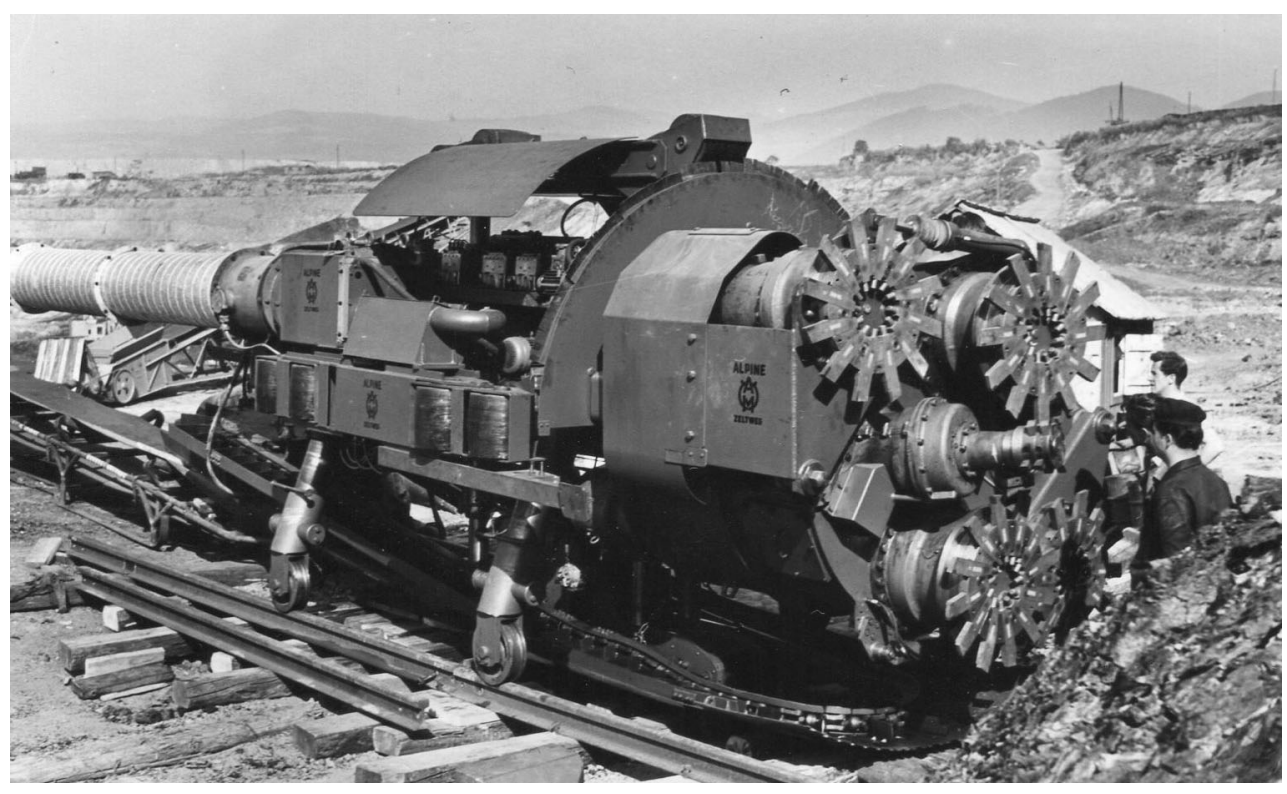


Figure 15: Sandvik MX650 Rapid Mine Development System as published in 2016 (Source: Sandvik Mining)

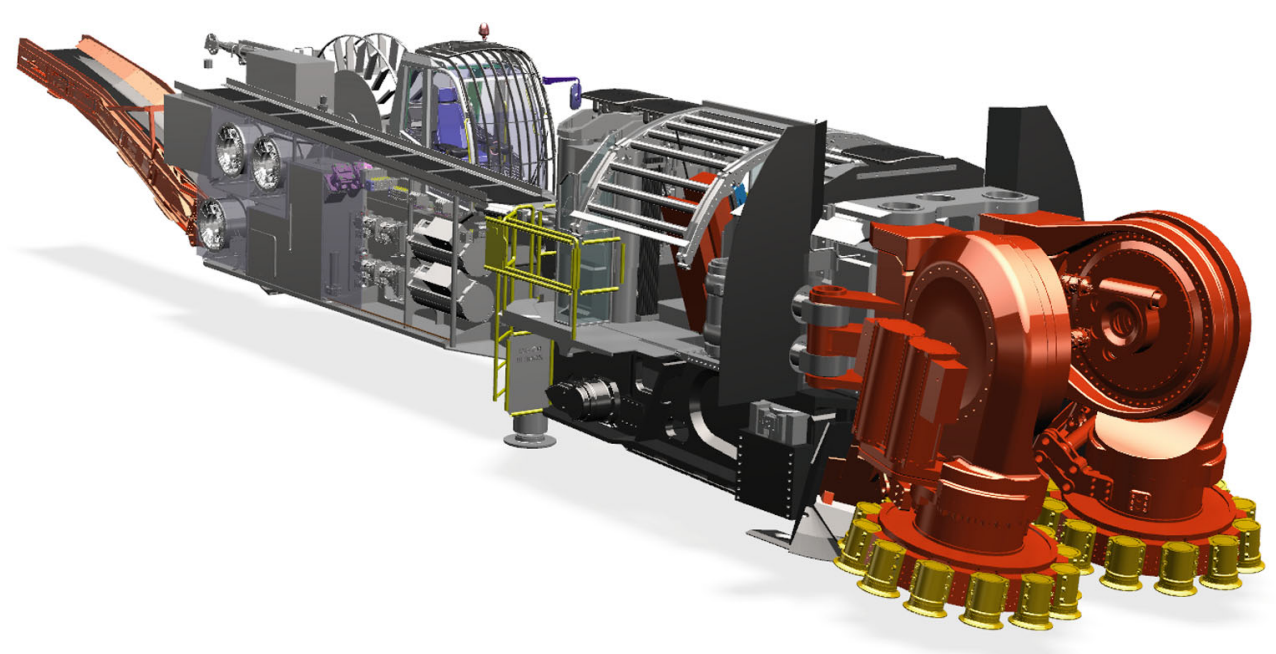

Figure 16: Rock extraction methods with major alternative methods (MUL)
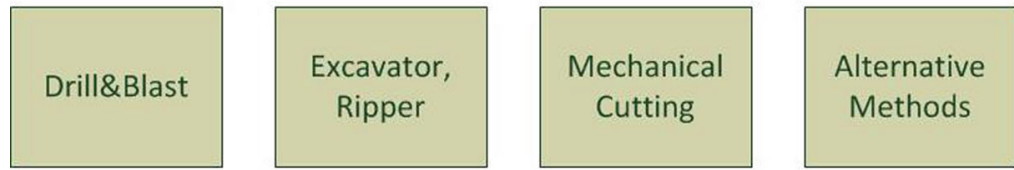

- Pick Tools

- Disk Tools

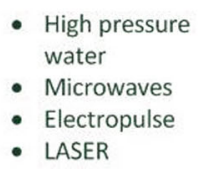

Combined Methods

- Microwave \& Cutting

- Microblasting \& Cutting

- Electropulse \& Cutting

\section{Principles of rock mass influence}

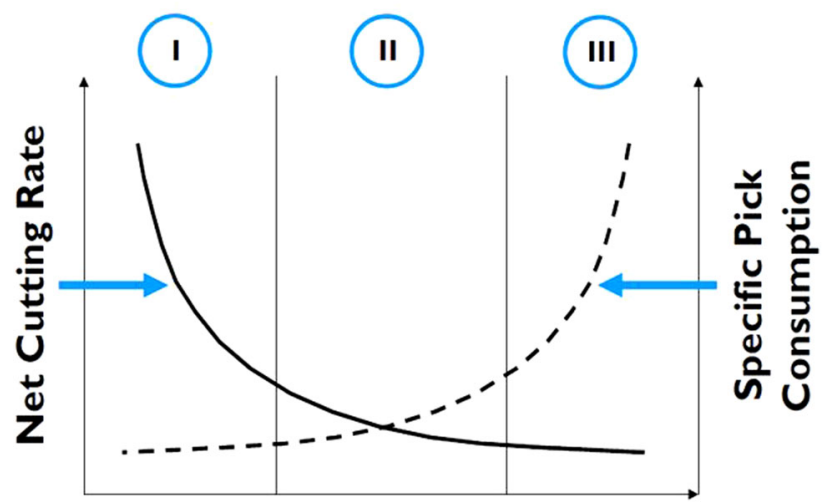

\section{Rock Mass Rating}

Figure 17: Influence of rock mass characteristics (defined by RMR) on net cutting rate (NCR) and specific pick consumption (SPC), (Source: Restner and Gehring 2002)

methods using LOX (liquid oxygen), new combined methods as listed in Fig. 16 are under development.

The rock mass rating (RMR) is a tool for quantifying the properties of the rock mass like uniaxial compressive strength, number of joints, condition of joint faces and some more. Figure 17 shows how a reduction of RMR will lead to an increase of performance parameters indicated by higher net cutting rate (NCR) and lower specific pick consumption (SPC).
The goal of alternative and hybrid combinations of alternative and classical rock extraction methods is therefore to artificially alter the RMR in a favourable way. This can be done by introducing artificial crack networks, generating slots/free surfaces or applying additional stresses on the rock surface by means of microwave irradiation, microblasting with LOX, activated cutting tools, high pressure water jets or Lasers.

Open access funding provided by Montanuniversität Leoben.

Open Access This article is distributed under the terms of the Creative Commons Attribution 4.0 International License (http://creativecommons. org/licenses/by/4.0/), which permits unrestricted use, distribution, and reproduction in any medium, provided you give appropriate credit to the original author(s) and the source, provide a link to the Creative Commons license, and indicate if changes were made.

\section{References}

1. Nordic Rock Tech Centre Project: Safer Charging of Bulk Explosives in Entry development, 2015, http://www.rocktechcentre.se/corebusiness/projects/ (3.9.2016)

2. Restner, U.; Plinninger, R. J.: Rock Mechanical Aspects of Roadheader Excavation, EUROCK 15, 64th Geomechanical Colloquium, Salzburg 2015

3. Girmscheid, G.: Baubetrieb und Bauverfahren im Tunnelbau, Table 7.9-1, Klassifizierung der TSM, 3. Auflage, Ernst \& Sohn, 2013

4. Sandvik -MGT Product Catalogue http://mining.sandvik.com/ SiteCollectionDocuments/products/tools/Sandvik-MGT-catalouge. pdf (3.9.2016)

5. http://www.e6.com/wps/wcm/connect/6dde14f2-07b2-4165-bb18cabbcd102011/E6_Combined+MiningTools_A4_28pp_English_awVIZ. 
pdf?MOD=AJPERES\&CACHEID=6dde 14f2-07b2-4165-bb18-cabbcd 102011 (16.01.2017)

6. Maid, I. B.; Schmid, L.; Ritz, W.; Herrenknecht, M.: Hardrock Tunnel Boring Machines, Ernst \& Sohn, Berlin 2008

7. Bilgin, N.; Copur, H.; Balci, C.: Mechanical Excavation in Mining and Civil Industries, Boca Raton, Florida: Taylor\&Francis, 2014

8. Herrenknecht Gripper-TBM Catalogue, https://www.herrenknecht. com/de/produkte/kernprodukte/tunnelling/gripper-tbm.html (2. 9 . 2016)

9. Cigla, M.; Yagiz, S.; Ozdemir L.: Application of Tunnel Boring Machines in Underground Mine Development, http://inside.mines.edu/ UserFiles/File/earthMechanics/tbm/tbm3.pdf (25.12.2016)

10. Williams, L.: Aker Wirth's MTM under way at Rio's Northparkes copper/gold mine, http://www.mineweb.com/archive/aker-wirths-mtmunder-way-at-rios-northparkes-coppergold-mine/ (2.9. 2016)

11. Aker Wirth Designing Mobile Tunnel Miner for Chilean Copper Mine, http://www.oemoffhighway.com/press_release/10874235/ aker-wirth-designing-mobile-tunnel-miner-for-chilean-coppermine (2.9.2016)

12. Ramström, M.: A Mining industry game changer, Atlas Copco News, 25 May 2016, http://www.atlascopco.com.au/auus/news/ companynews/a-mining-industry-game-change.aspx. (25.12.2016)

13. Caterpillar, Rock Straight System, http://www.cat.com/en_ZA/ campaigns/awareness/rock-straight-system.html (3.9.2016)

14. CDC Technology, https://www.australianmining.com.au/features/ dynacut-oscillating-disc-cutter-technology-achieving-breakthroughs/ (16.01.2017)

15. Leonida, C.: Making hard-rock history, Mining Magazine July/ August 2016, p. 52-61

16. Wohlmeyer, J.: Machine for Boring Galleries, Tunnels, Channels and the Like by Cutting Action, US Patent US 2,758,825, Aug.14, 1956 